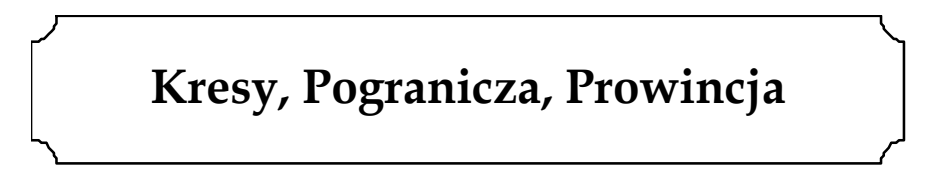

\title{
MELANCHOLIA DYSKURSU KRESOZNAWCZEGO
}

\author{
DARIUSZ SKÓRCZEWSKI ${ }^{1}$ \\ (Lublin)
}

\begin{abstract}
Słowa kluczowe: melancholia, Zygmund Freud, psychoanaliza, „Kresy”, dyskurs kresoznawczy, postkolonializm

Keywords: melancholia, Sigmund Freud, psychoanalysis, "Borderlands", Polish "Borderland" discourse, postcolonialism
\end{abstract}

\begin{abstract}
Abstrakt: Dariusz Skórczewski, MELANCHOLIA DYSKURSU KRESOZNAWCZEGO. „PORÓWNANIA" 11, 2012, Vol. XI, s. 125-138, ISSN 1733-165X. Poszukując odpowiedzi na pytanie o przyczyny trudności, jakie sprawia Polakom rozpoznanie i krytyczne opisanie swej obecnej postkolonialnej tożsamości, autor odwołuje się do pojęcia melancholii, dostrzegając w niej kategorię interpretacyjną pozwalającą objaśnić postkolonialną kondycję Polski w kontekście „kresowym" i wynikające stąd współczesne problemy Polaków z autodefinicją. Freudowska koncepcja melancholii stanowi proponowane narzędzie analizy praktyk panujących na terenie tzw. dyskursu kresoznawczego. Dyskurs ten podtrzymuje wśród jego użytkowników poczucie Freudowskiej melancholii i subtelnie skłania do trwania w tym stanie. Podczas gdy tradycyjne podejścia badawcze, w znacznej części przemycające postawę tęsknoty za świetną przeszłością polsko-litewskiej Rzeczypospolitej, utrudniają Polakom pogodzenie się ze swą postkolonialną kondycją jako dawnych kolonizatorów i skolonizowanych, przyszłe studia postkolonialne nad dyskursem kresoznawczym nie powinny poprzestać na krytyce status quo, a raczej uczynić postkolonialną melancholię obiektem swoich badań, lokując ją jednak bezwzględnie w szerszym kontekście rosyjskiego i sowieckiego kolonializmu.
\end{abstract}

Abstract: Dariusz Skórczewski, THE MELANCHOLY OF THE BORDERLAND DISCOURSE. "PORÓWNANIA" 11, 2012, Vol. XI, pp. 125-138, ISSN 1733-165X. In seeking to answer the question why Poles are having difficulties in recognizing and critically describing their present postcolonial identity, the author refers to the notion of melancholia as an important interpreta-

\footnotetext{
${ }^{1}$ Correspondence Address: dareus@kul.pl
} 
tive category for illuminating the postcolonial condition of Poland in relation to its former Eastern territories, known as "Borderlands," and accounting for the nation's present problematic self-definition. The paper adopts the Freudian concept of melancholia to the study of discursive practices of the so-called Polish "Borderland" discourse. This discourse reinforces the view that Poles are in a condition of Freudian melancholia and subtly encourages the Poles to remain in such a condition. While traditional critical approaches to a great extent implicitly smuggle the attitude of yearning for the splendid past of the Polish-Lithuanian Republic and thus prevent Poles from coming to terms with their postcolonial condition as both "colonisers" and colonised, the prospective postcolonial studies in the "Borderland" discourse should not stop at the critique of this status quo. Instead, it should make the Polish postcolonial melancholia an object of scrutiny by placing this melancholia within the broader context of Russian and Soviet colonialism.

Wśród różnych odmian melancholii istnieje też taki jej rodzaj, który teoretycy określają jako „postkolonialna melancholia”2. Można ją zdefiniować jako kolektywną "chorobę duszy" tych populacji, które w następstwie skolonizowania postrzegają siebie jako bezsilne, słabe, zacofane czy wręcz pozbawione wartości. Autopercepcja ta cechuje się, znamienną dla kondycji postkolonialnej, ambiwalencją. $\mathrm{Z}$ jednej strony przejawia się nostalgią za minioną wielkością, z drugiej zaś - samoobwinianiem za obecne niedociągnięcia, porażki i wady.

Sigmund Freud, do którego koncepcji tu nawiązuję, uważał, że w przypadku niektórych ludzi melancholia, podobnie jak żałoba, stanowi „reakcję na utratę ukochanej osoby czy też zajmującej jej miejsce abstrakcji w rodzaju ojczyzny, wolności, ideału itd."3. Tego rodzaju melancholia, twierdził twórca psychoanalizy, nie jest jednak tożsama z żałobą. O ile prawidłowo przeżyta, zdrowa żałoba zrzeka się opłakanego obiektu, niejako zwraca samemu sobie tak ów obiekt, jak i podmiot żałoby, melancholia prowadzi podmiot do budowania własnej tożsamości na ciągłym rozpamiętywaniu, i hiperbolizowaniu, poniesionej straty, co owocuje zgoła odmiennymi konsekwencjami. Wedle objaśnień Freuda, melancholia wynika $\mathrm{z}$ "patologicznego usposobienia”, a cechuje ją „brak zainteresowania światem zewnętrznym, [...] zahamowanie wszelkich działań i obniżenie poczucia własnej wartości, które przejawia się $\mathrm{w}$ wyrzutach wobec samego siebie i znieważaniu siebie" 4 .

Wydaje się, że pewne cechy opisanej przez Freuda melancholii dochodzą do głosu w polskim dyskursie kresoznawczym, a także w innych obszarach polskiego dyskursu tożsamościowego, które - pomimo braku bezpośredniego związku

2 Zob. np. P. Gilroy, Postcolonial Melancholia. New York 2005.

${ }^{3}$ S. Freud, Żałoba i melancholia. Przeł. B. Kocowska, w: K. Pospiszyl, Zygmunt Freud, człowiek i dzieło. Wrocław 1991, s. 295.

${ }^{4}$ Ibidem, s. 295-296. 
z „Kresami” - pozostają przecież refleksem samopostrzegania podmiotu. „Dyskurs kresoznawczy" rozumiem tu szeroko: jako kategorię obejmującą zarówno "piśmiennictwo kresowe", a więc dyskurs literacki ${ }^{5}$, związany w zakresie szeroko pojętej tematologii z polskimi „Kresami Wschodnimi” jako formacją historycznoterytorialną ${ }^{6}$, jak i dyskursy popularnonaukowe, krytyczne i naukowe ( $\mathrm{w}$ tym literaturoznawczy, historyczny, socjologiczny, etnograficzny), mające za przedmiot właściwe danej dziedzinie typy zjawisk, które historycznie lub geograficznie można powiązać $\mathrm{z}$ „Kresami”. Wydaje się to usprawiedliwione ich wspólną referencjalną naturą: "Kresy” jako temat twórczości artystycznej spotykają się tu $\mathrm{z}$ „Kresami” jako przedmiotem dyskursywnego opisu w tym samym, prawdziwościowym i aksjologicznym, wymiarze.

Edward Kasperski zauważył, że

paradoks literatury kresowej XIX w. staje się [...] paradoksem heglowskiej świadomości nieszczęśliwej, gdyż mitologizacja kresowości ożywa i rozkwita w zasadzie ex post, w sytuacji, w której historyczna realność Kresów staje się problematyczna lub zgoła rozpada się i przechodzi w niebyt. Pojawia się w momencie, w którym Polska traci na Kresach hegemonię i kiedy na dobre rozpoczyna się agonia rzeczywistości kresowej pod wpływem podziału Kresów pomiędzy zaborców oraz gwałtownego budzenia się wśród Ukraińców, Litwinów czy Białorusinów świadomości narodowej

Jeśli obrać Heglowskie das unglückliche Bewußtsein, nieszczęśliwą świadomość "podzieloną", za punkt wyjścia do opisu zjawiska dyskursu kresoznawczego, to uznanie zaproponowanej tu Freudowskiej kategorii melancholii za instrument analizy tym bardziej nie powinno nastręczać trudności. Interpretacja freudowska pozwala, w moim przekonaniu, nie tylko na pełniejsze, bo wzbogacone o dynamikę procesu godzenia się ze stratą, ujęcie omawianej problematyki, lecz także pośrednio udziela odpowiedzi na dręczące pytania, stawiane przez takich krytyków tradycyjnych ujęć badawczych, jak Daniel Beauvois ${ }^{8}$ czy Bogusław Bakuła9. Wydaje się, że uwzględnienie postkolonialnej kondycji polskiego dyskursu naukowego stanowi warunek wstępny dalszej eksploracji tych zagadnień.

${ }^{5}$ Odpowiadałoby to częściowo, wyróżnionemu przez E. Kasperskiego (Dyskurs kresowy. Kryteria, własności, funkcje, w: Kresy. Dekonstrukcja. Red. K. Trybuś, J. Kałążny, R. Okulicz-Kozaryn. Poznań 2007, s. 92), historycznoliterackiemu znaczeniu kategorii „literatura kresowa”.

6 Myślę o terytoriach położonych na wschód od teraźniejszych granic Polski, znajdujących się przed rozbiorami w obrębie Rzeczypospolitej, a obecnie należących do Białorusi, Litwy i Ukrainy.

${ }^{7}$ E. Kasperski, op. cit., s. 97.

8 D. Beauvois, Trójkąt ukraiński. Szlachta, carat i lud na Wotyniu, Podolu i Kijowszczyźnie 1793-1914. Przeł. K. Rutkowski. Lublin 2011; idem, Mit "kresów wschodnich”, czyli jak mu położyć kres, w: Polska myśl polityczna XIX i XX wieku, t. 9: Polskie mity polityczne XIX i XX wieku. Red. W. Wrzesiński. Wrocław 1994.

9 B. Bakuła, Kolonialne i postkolonialne aspekty polskiego dyskursu kresoznawczego (zarys problematyki). „Teksty Drugie” 2006, nr 6. 
Przegląd prac na temat „Kresów” i problematyki „kresowej”, jakie ukazały się w ostatnich latach (od 1989 r.), komplikuje jednak nieco tę optymistyczną prognozę. Lektura niektórych wypowiedzi nasuwa raczej wniosek, iż próby krytycznego przemyślenia dyskursu kresoznawczego bywają interpretowane jako pogwałcenie narodowego "kodeksu honorowego", a wprowadzenie dyskursu kresoznawczego $\mathrm{w}$ orbitę studiów postkolonialnych traktowane jest wręcz w kategoriach apostazji:

Przechrztami nazywam krytyków, którzy literaturę kresową próbują przechrzcić i przezwać „literaturą kolonialną". Piszą, że jest ona wyrazem polskiego kolonializmu, przejawem kolonialnej (postkolonialnej) świadomości. [...] Literatura kresowa podobno ciągle akcentuje polskie poczucie wyższości i niezbywalne prawo panowania nad narodami kresowymi, neguje ich zdolności do samodzielnego bytu, eksponując swój imperialny polonocentryzm i ksenofobię. Przechrzty usiłują dowieść, że literatura kresowa ma "kolonialne jądro" i nie jest zdolna do prawdziwego dialogu z Ukraińcami, Białorusinami i Litwinami [...] Trzeba, mówią, zdekolonizować naszą mentalność, myślenie, wyobraźnię i język i dopuścić do głosu Innych ${ }^{10}$.

W dyskusji ze stanowiskiem postkolonialnym, prowadzonej z tak zdefiniowanych pozycji, padają przede wszystkim argumenty historyczne, których referowanie wykracza poza skromne ramy tego tekstu ${ }^{11}$. Podkreślenia natomiast wymaga fakt, iż w powszechnej mentalności - a podziela ją, choćby z przyczyn biograficznych, wielu badaczy tych zagadnień - „Kresy” wciąż stanowią symbol nieodwracalnej straty, jednej z największych i najboleśniejszych traum, jakich doświadczyli Polacy $\mathrm{w}$ ostatnich dwóch stuleciach. Ujęte $\mathrm{w}$ taką ramę modalną, narracje artystyczne i naukowe na tematy "kresowe” zawierają nieuniknione odniesienia do utraconych terytoriów położonych niegdyś w granicach Rzeczypospolitej, a przez to - do utraconej części polskiej genealogii narodowej, i tym samym również polskiej podmiotowości.

Charakter tej straty jest niejednoznaczny, a ona sama wymaga dalszych rozróżnień. Dla tych, którzy przechowują w zasobach pamięci resp. pokładach podświadomości traumatyczne wspomnienia przymusowego wysiedlenia z rodzinnej ziemi, nazywanego eufemistycznie repatriacją, stała się ona kluczowym doświadczeniem formacyjnym lub po prostu nieusuwalnym składnikiem psychologicznego archiwum. Przekonują nas wciąż o tym, bardzo zróżnicowane, próby uporania się - via literatura, pojmowana jako obszar ewokacji „dziejów zaświadczonych"12 -

${ }^{10}$ B. Hadaczek, Kresówki (Kresy w literaturze polskiej). Szczecin 2011, s. 145-146.

11 Ibidem, s. 146. O trudnościach związanych z przenoszeniem kategorii zachodniego postkolonializmu na dzieje kontaktów I Rzeczypospolitej z południowo-wschodnimi obszarami Europy pisał Jan Kieniewicz w książce Ekspansja. Kolonializm. Cywilizacja. Warszawa 2008, s. 170-171 i nast.

12 Nawiązuję do eseju J. Jedlickiego Dzieje doświadczone i dzieje zaświadczone, w: Dzieło literackie jako źródto historyczne. Red. Z. Stefanowska, J. Sławiński. Warszawa 1978, a także do koncepcji literatury jako ewokacji, rozwijanej przez Stefana Sawickiego (zob. Stefan Sawicki, Czym jest poezja?, w: Wartość - sacrum - Norwid. Lublin 1994). 
z traumą wypędzenia $\mathrm{z}$ „Kresów”, podejmowane przez takich pisarzy, jak Włodzimierz Odojewski, Aleksander Jurewicz, Włodzimierz Paźniewski czy Stanisław Lem. Relacjonowane za pośrednictwem twórczości autobiograficznej i fikcjonalnej, a także w opracowaniach historiograficznych i tekstach dokumentarnych - reportażach, rozmowach itp., doświadczenie to wyraża się szczególną "kresową" nostalgią za utraconą na zawsze przestrzenią i czasem, tak dobrze komunikowaną „Z duszy do duszy” i jednocześnie tak trudno przekładalną na obce idiomy artystyczne i inne niż polski rejestry wrażliwości. Rozpatrywane $\mathrm{z}$ tej perspektywy "Kresy” stają się czymś więcej niż tylko, poddaną szczególnej estetyzacji, „poetologiczną przestrzenią wolności”13 czy "nierzeczywistą rzeczywistością"14. Dla tych, którzy nie zostali osobiście poddani temu szczególnemu rodzajowi "przemieszczenia”, jakim była ekspatriacja z "kresowej ojczyzny”, przechowywana w pamięci utrata sama stała się "przemieszczonym" doświadczeniem. Pozbawiona swego pierwotnego znaczenia, bo oderwana od indywidualnego przeżycia tych, którzy zostali nią bezpośrednio naznaczeni, przekształciła się w intersubiektywny brak odczuwany przez ogół populacji, stając się częścią składową „polskiego losu".

Mamy tu do czynienia ze swoistym paraliżem tożsamości - niedowładem, który przejawia się popadnięciem w fundamentalną, trudną do sprecyzowania, lecz odczuwaną przez wspólnotę bezsilność, niemoc - oznakę melancholii. Otóż postkolonialnej refleksji krytycznej wymaga nie tyle żałoba po utraconych terytoriach czy też nostalgia związana z ich dawną rolą, co właśnie owa melancholia, której wehikułem jest dyskurs kresoznawczy. Melancholia ta bowiem, parafrazując znane stwierdzenie Edwarda Saida, nie jest niewinna. Kryje w sobie ślady resentymentu, utrudniającego Polakom rozpoznanie swej obecnej postkolonialnej kondycji i zmierzenie się z nią. Melancholia - w znaczeniu, o którym tu mowa sprawia, iż jej podmiot obraca się jakby nieustannie w świecie symulakrów, substytutów rzeczywistości, „koniecznych fikcji”15, kultywując cierpienie wskutek doświadczonego zubożenia. Zubożenie to jednak należy rozumieć nie tyle jako fizyczną utratę terytorium, co raczej w kategoriach jednostkowej i kolektywnej traumy kulturowego wydziedziczenia - jako wspomniany brak, ontologiczną niekompletność, boleśnie odczuwaną deprywację.

W ten sposób melancholia o podłożu „kresowym” przybiera bardziej konkretny, freudowski kontur. Zamiast bowiem stymulować „zdrową żałobę", której istotą jest opłakanie straty, pogodzenie się z nią i powrót do normalnego funkcjono-

${ }_{13}$ G. Ritz, Kresy polskie w perspektywie postkolonialnej, w: Nieobecność: pominięcia i przemilczenia w narracjach XX wieku. Red. H. Gosk, B. Karwowska. Warszawa 2008, s. 118.

14 Sformułowanie zaczerpnięte z tytułu książki M. Dąbrowskiego Nierzeczywista rzeczywistość. O twórczości Andrzeja Kuśniewicza. Warszawa 2004.

${ }^{15} \mathrm{H}$. Bhabha, Representation and the Colonial Text: A Critical Exploration of Some Forms of Mimeticism, w: The Theory of Reading. Red. F. Gloversmith. Brighton 1984, s. 97. 
wania, pokaźna część dyskursu kresoznawczego oddaje się melancholii, która w rozumieniu Freuda - jest patologicznym substytutem żałoby. W rezultacie strata jawi się jako nieuchwytna, niesubstancjalna, trudna do zdefiniowania. Poraża swą totalnością, ogarnia wszystkie wymiary narodowej egzystencji. Nie chodzi tu już jedynie o to, że Polacy utracili część dawnego dominium. Strata, którą celebrują za pośrednictwem dyskursu kresoznawczego, odrywa się od swego pierwotnego podłoża i podlega autonomizacji, a więc - jak u Freuda - przekształca się raczej w przedmiot wewnętrzny, psychiczny, niż pozostaje konkretnym, zewnętrznym wobec podmiotu, obiektem ${ }^{16}$.

W odróżnieniu od żałoby, tudzież nostalgii za utraconym obiektem, w odniesieniu do którego podmiot pozostaje odrębny i zdystansowany, Freudowska melancholia jest wewnętrznym stanem podmiotu, który trwa w narcystycznym utożsamieniu z utraconym obiektem po uprzednim włączeniu go do swej tożsamości. Podmiot melancholii wciąż rozgrywa $\mathrm{w}$ swojej podświadomości traumatyczne wspomnienie utraty obiektu miłości. „Potrzebuje” tego obiektu, stanowiącego jego dopełnienie, do takiego stopnia, iż obiekt ten staje się dla podmiotu newralgicznym czynnikiem definiującym i konstytuującym tożsamość. W konsekwencji doświadczający melancholii podmiot cierpi wskutek uporczywego braku, którego nie sposób zrównoważyć i który nie może znaleźć innego ujścia, jak przypominanie przeszłej zbiorowej traumy, w nadziei na odzyskanie utraconej cząstki ,ja". To ambiwalentne poczucie braku i nadzieję na jego kompensację za pomocą dyskursu, traktowanego jako instrument „wyobrażeniowego zawłaszczenia”, odnotował Jerzy Stempowski w 1967 r. w znamiennych słowach: „Najpiękniejszą i najmniej kłopotliwą formą posiadania ziemi na prawach historycznych wydaje mi się nasze obecne posiadanie dawnych kresów wschodnich. Posiadamy je nadal w pamięci, w literaturze, w muzeach" 17 .

Pogląd wyrażony przez Stempowskiego - pisarza o jakże niepolonocentrycznych zapatrywaniach - potwierdza jedną z centralnych tez teorii postkolonialnej, mianowicie że dyskurs kolonialny „nie musi być wcale bezpośrednią wypadkową konkretnych ambicji terytorialnych. Może też być wynikiem pewnej mapy mentalnej"18. Autor listu do Marii Czapskiej przyznaje, że nadal chodzi o „posiadanie

16 E. Kasperski (op. cit., s. 103) wskazuje na "autoreferencjalność” dyskursu „postkresowego", tj. jego swoistą "pretekstowość” i „fikcjonalność”. Współczesny dyskurs kresowy po 1945 r. stanowi, zdaniem badacza, „pustkę denotacyjną”. Dostrzeżenie w tym dyskursie przejawu postkolonialnej melancholii zmienia, jak sądzę, kwalifikację nadaną mu przez Kasperskiego.

17 A. St. Kowalczyk, Rozpad języka poprzedzit trąbe jerychońską... List Jerzego Stempowskiego do Marii Czapskiej. „Regiony” 1995, nr 2, s. 105.

${ }^{18}$ K. Łozowska, Postcolonial studies. Przypadek polski, w: 20 lat literatury polskiej 1989-2009. Idee, ideologie, metodologie. Red. A. Galant, I. Iwasiów. Szczecin 2008, s. 152. Autorka odnosi to wprawdzie do sytuacji podporządkowania, lecz istnienie swoistych „map mentalnych” dotyczy również dyskursu hegemonicznego. 
ziemi", przy czym nie tylko uznaje dopuszczalność tego, co nazwałem tu zawłaszczeniem wyobrażeniowym, lecz także przykłada do tej formy "tekstualnego posiadania" wymowny podwójny superlativus. Stwierdzeniu temu niedaleko już do myśli, iż „melancholia nie jest jedynie przywiązaniem do utraconego przedmiotu, lecz przywiązaniem do pierwotnego gestu jego utraty"19. Nie będzie chyba przesadnie ryzykowna teza, że to postkolonialna melancholia stanowi istotne źródło tak licznych w naszym piśmiennictwie tekstów, których „mapa mentalna” zorientowana jest według wektora straty i w których strata ta jest $\mathrm{w}$ coraz to nowych odsłonach przypominana, rozpatrywana i przedstawiana - również przez tych autorów, dla których wypędzenie z „Kresów” było jedynie doświadczeniem „z drugiej ręki”20.

Dyskurs kresoznawczy stał się $\mathrm{w}$ ostatnich latach przedmiotem uwagi rodzących się studiów postkolonialnych. Podobnie jak w przypadku zachodnioeuropejskiego postkolonializmu, towarzyszy mu aura „imperialnej winy”, przez co badania nad nim jawią się poniekąd jako forma zadośćuczynienia wobec spolonizowanych narodów dawnej Rzeczypospolitej: Białorusinów, Litwinów, Ukraińców. Narody te - zwraca się uwagę - uważane były w strukturze "szlacheckiego imperium" 21 za peryferyjne, marginalne dla polskiego centrum kulturalnego, a w konsekwencji pozbawione podmiotowości i roli sprawczej. Studia postkolonialne mają umożliwić tym grupom odzyskanie zdolności samoartykulacji, oddając im w ten sposób sprawiedliwość. Podnosi się, iż dyskurs kresoznawczy to jaskrawy przykład etnocentrycznego dyskursu hegemonicznego, który dokonywał - i nadal dokonuje 22 - orientalizacji innych grup etnicznych i kultur. Stąd wysuwane co jakiś czas postulaty oczyszczenia języka prac poświęconych „Kresom" z hegemonicznego nalotu. Naleciałości te bowiem, choć należą "zaledwie" do sfery pojęć, nie zaś do obszaru "twardych" faktów politycznych, mają "siłę rażenia" równie potężną jak posunięcia władców czy wojsk: ograniczają, więżą, odzierają z suwerenności, odbierają podmiotowość, eliminują.

${ }^{19}$ S. Žižek, Melancholy and the Act. „Critical Inquiry” Summer 2000, nr 4 (26), s. 660.

${ }^{20}$ Np. Adam Zagajewski, Andrzej Jurewicz, Marek Ławrynowicz, Anna Bolecka czy Włodzimierz Paźniewski.

${ }^{21}$ Wzięcie tej frazy w cudzysłów służy podkreśleniu problematyczności imperialnego statusu państwa polsko-litewskiego, na co zwracał uwagę m.in. Jan Kieniewicz w swojej książce Ekspansja, kolonializm, cywilizacja (Warszawa 2008), w części zatytułowanej Doświadczenie polskie, doświadczenie pogranicza.

22 Zob. F. Wasyl, Kresy wschodnie jako kolonialna metafora historiografii polskiej: postkolonialna perspektywa badań historiografii narodowej, w: Obcy - Obecny. Literatura, sztuka i kultura wobec inności. Red. P. Cieliczko, P. Kuciński. Warszawa 2008, s. 77. 
Rzeczywiście, po lekturze Orientalizmu nie można przejść do porządku dziennego nad deformującymi kategoriami, jakie nakładamy na "Innych” bez pełnej szacunku akceptacji dla ich "inności”. Dotyczy to także dyskursu kresoznawczego. Nie sposób podtrzymywać dziś mistyfikacji, iż podejmując się opisu naukowego pewnego wycinka rzeczywistości, robimy to z niewzruszonych, uniwersalistycznych pozycji. Argumenty krytyków dyskursu kresoznawczego wydają się więc uzasadnione. Czy wobec tego wpisywanie tego dyskursu w kontekst polskiej hegemonii to jedyna "słuszna" jego interpretacja, a on sam zasługuje wyłącznie na krytykę jako archiwum czy też wylęgarnia „nierozumiejących” postaw imperialnych?

Obecność w dyskursie kresoznawczym „nostalgii” i „czaru”, o których tak krytycznie pisał D. Beauvois²3, można wytłumaczyć na gruncie - pojmowanej po freudowsku - melancholii. Jak każda melancholia, i ta powoduje, że jej podmiot nie może "nie chcieć" tego, co niezbędne mu do samopoznania i samookreślenia. Jest ona $\mathrm{w}$ istocie nostalgią Polaków za częścią utraconego wizerunku samych siebie. Poszukiwanie i rekonstruowanie tego kolektywnego autoportretu utrudnia, a niekiedy wręcz uniemożliwia podmiotowi postrzeganie Innych jako obiektu dominacji - nawet jeśliby to miała być jedynie dominacja dyskursywna. Ufundowany na opisanej tu melancholii, szczególny styl percepcji kresowego chronotopu, z jakim mamy do czynienia $w$ dyskursie kresoznawczym, otwiera pole dla mitologizacji zarówno owych Innych, jak i stosunku zajmowanego wobec nich przez polski podmiot. Owocuje to narracjami, tak artystycznymi, jak i autobiograficznymi oraz naukowymi, w których polskość splata się z „innością" w najzupełniej naturalnej i obopólnie korzystnej symbiozie, a „Kresy” stanowią uniwersalną przestrzeń spotkania, dialogu, otwarcia. Zbigniew Żakiewicz w eseju noszącym wymowny tytuł Polska jest wciąż Kresami ujął to następująco:

Z biegiem lat Kresy stały się dla mnie ojczyzną duszy, ziemią mityczną i metafizyczną. Aż wreszcie, już w dojrzałości, pojąłem, że kresowość jest czymś bliskim dla całej polskości, jeśli ma być ona żywa, otwarta na inność, miłująca "małe ojczyzny" i dążąca do Uniwersum ${ }^{24}$.

W wyniku tego rodzaju mitologizacji przesłonięciu ulega fakt, iż dyskurs na niej wznoszony ześrodkowany jest wokół polskiego podmiotu i z jego pozycji jest prowadzony, a miejsce, znaczenia i wartości, przypisywane owym Innym, są ściśle zdefiniowane przez przyjęty punkt widzenia i regulowane partykularnymi roszczeniami o podłożu narodowym i etnokulturowym, niezależnie od kamuflujących je, uniwersalistycznych pretensji.

23 ...prawdę mówiąc - nie jest jasne, dlaczego Ukraina nadal wypełniała duszę przeciętnego Polaka nostalgią i czarem nawet za czasów komunistycznych" (D. Beauvois, Trójkąt ukraiński, op. cit., s. 17).

24 Z. Żakiewicz, Polska jest wcią̇̇ Kresami. „Ethos” 1992, nr 2/3, s. 293. 
Podmiot dyskursu kresoznawczego jest przecież historycznie i geograficznie, a nawet geopolitycznie, uwarunkowany. Ponawiając - za pomocą inscenizowanej kulturowo melancholii - "gest utraty", stara się ocalić swą tożsamość i integralność, narażone na szwank w wyniku rosyjskiej i sowieckiej hegemonii. Wysiłki te nieuchronnie przybierają postać szczególnego rodzaju narcyzmu, który uznać można za uboczny produkt podporządkowania, natomiast $\mathrm{w}$ melancholii, jaka z tego narcyzmu wypływa, odsłania się instrument kulturowej "samoobrony". Melancholia ta jest bowiem próbą przezwyciężenia wspomnianej "wyrwy” w tożsamości, np. za pomocą estetyzacji i mitologizacji „Kresów”. Z tej perspektywy dyskurs kresoznawczy można postrzegać jako deformujące lustro, w którym przegląda się postkolonialny podmiot, nie zdając sobie do końca sprawy ze swej postkolonialnej kondycji. Współczesna psychologia, rozpatrując to zjawisko na poziomie jednostkowym, wskazuje na szczególny charakter tego rodzaju narcyzmu. Wypływa on z zaburzeń $\mathrm{w}$ zakresie autoekspresji, spowodowanych m.in. wielokrotnie ponawianymi aktami upokorzenia ${ }^{25}$. "Wszystkie jednostki narcystyczne żyją pod presją nierozwiązanego napięcia między wielkościowością a bezwartościowością" 26 . Te dwie skrajności nazbyt dobrze charakteryzują polską literaturę i dyskurs publiczny minionych dwustu lat 27 . Polskie "ja” jawi się w nich wielokrotnie jako struktura defensywna i wycofana, która wypatruje aprobaty $\mathrm{u}$ innych oraz uprzedza ich oczekiwania i żądania, z wyjątkową wrażliwością reagując „na lekkie nawet sygnały nieakceptacji albo na najmniejszą porażkę" 28 . Zagłębia się w narcystycznych iluzjach na swój temat, owych „koniecznych fikcjach”, które stają się jedynym źródłem narodowego samouznania, poczucia własnej wartości, a przy tym stanowią rodzaj kompensacji i zarazem modelują określony styl odbioru dyskursu kresoznawczego - styl, rzecz jasna, afirmatywny.

Wobec wpisywania "Kresów” w zakres przedmiotowy studiów postkolonialnych część historyków literatury zachowuje jednak rezerwę ${ }^{29}$. Badacze, którzy chcieliby się zastosować do sugestii płynących z teorii postkolonialnej, krytykowani są za próby „ponownego przemyślenia” dyskursu kresoznawczego. Sceptycyzm ten opiera się na dwóch, ściśle ze sobą związanych, przeświadczeniach:

25 S. M. Johnson, Style charakteru. Przeł. B. Mizia. Poznań 1998, s. 56.

${ }^{26}$ Ibidem.

${ }^{27}$ Choć niektórzy polscy krytycy (np. K. Dunin, Literatura polska czy literatura w Polsce? „Ex Libris” Marzec 1994, nr 48, zgłaszają podobne rozpoznania, nie zwracają na ogół uwagi na postkolonialny kontekst tego zjawiska.

28 S. M. Johnson, op. cit., s. 56.

${ }^{29} \mathrm{~Np}$. T. Bujnicki (O problemach kultury i literatury pogranicza. Kilka impresji badawczych, w: Aktual'nye problemy inoz'emnoy filologii: lingvistyka ta literaturoznavstvo. Mizhvuzivski zbirnik naukovykh statej. Vipusk 1, Nizhin 2007, s. 185) przestrzega: „Wydaje się [...], że narzędzia te, przeniesione z badań nad stosunkami w krajach zdobywających kolonie w XIX wieku i tworzącym imperia kolonialne nie do końca pasują do badań nad procesami mniej gwałtownymi i w których w różnym czasie trwała 'wymiana' zasady podległości i dominacji”. 
1) o niepodważalnej wartości twórczości „kresowej” dla dyskursu tożsamościowego oraz 2) o niebezpieczeństwie, jakie przedstawiają dla kultury narodowej tego rodzaju zabiegi metodologiczne przez to, iż dezawuują - zdaniem sceptyków - pisarstwo "kresowe”, podkopując tym samym, budowaną na polskości „Kresów", współczesną polską tożsamość, nadwątloną przez rosyjską i sowiecką kolonizację. Niektórzy wreszcie po prostu przyznają, odwołując się explicite do rejestrów języka melancholii, że „niełatwo jest pogodzić się ze stwierdzeniem profesora Daniela Beauvoisa o tym, by w końcu położyć kres kresowym mitom, skończyć raz z nostalgią za utraconym bezpowrotnie rajem, gdzie dobry Bóg przymykał oko na grzechy jego mieszkańców"30.

Czy uczonym zgłaszającym tego rodzaju wątpliwości należy zarzucać hołdowanie ambicjom kolonialnym tudzież pielęgnowanie imperialnej nostalgii? Wielu z nich zdaje sobie sprawę, że „winniśmy naszym wschodnim sąsiadom zrozumienie i pomoc, a nie jakąś szabelkowatą postawę rewindykacyjną" ${ }^{31}$. Rozumieją oni również, że celem opisu naukowego nie jest "poprawiactwo" 32 przeszłości, a jej gruntowniejsze i pełniejsze, wieloaspektowe poznanie, wzbogacone o różne punkty widzenia. Uprawianie dyskursu kresoznawczego $w$ intencji ochrony czy też obrony wyjątkowej wartości kultury „Kresów” dla Polski, lecz bez uwzględnienia kwestii podnoszonych m.in. przez teoretyków postkolonializmu, możliwe jest istotnie tylko za cenę lekceważenia perspektywy "Innych" - pisarzy i badaczy ukraińskich, litewskich czy białoruskich.

Dystans wobec "postkolonializacji” dyskursu kresoznawczego wydaje się na pozór mieć u podstaw tę samą melancholię, która od czasów romantyzmu (a w okresie PRL i tuż po 1989 r. ze wzmożoną energią) dostarcza energii polskiemu dyskursowi tożsamościowemu, tak w jego wymiarze antykolonialnym (opór wobec zaborczych imperiów), jak i kolonialnym (orientalizacja „Kresów”, słabe wyczulenie na dążenia narodowościowe ich niepolskich mieszkańców, czyli w modnym żargonie "marginalizacja Innych"). Melancholia ta daje o sobie znać w "strukturach języka, w obrazach, w nakreślonych ścieżkach badawczych, w metodzie, $\mathrm{w}$ świadomości przechowującej wciąż ten sam postulat "polonizacji« wielonarodowego dziedzictwa historycznego" ${ }^{33}$. Składniki te wniknęły już głęboko w dyskurs literaturoznawczy, przez co pełnią funkcję przeźroczystych i neutralnych ideologicznie narzędzi badawczych, podczas gdy w rzeczywistości magazynują w sobie, nawet jeśli niezamierzony, ładunek dominacji dyskursywnej. Wystarczający to argument na rzecz tezy, iż dyskurs tożsamościowy, oparty na bezkrytycznym eksponowaniu polskości „Kresów”, ma charakter wykluczający i nosi zna-

\footnotetext{
${ }^{30}$ K. Łozowska, „Obca” ojczyzna: szkice i eseje historycznoliterackie. Szczecin 2004, s. 89.

31 T. Chrzanowski, Kresy czyli obszar tęsknot. Kraków 2001, s. 7.

32 Ibidem, s. 15.

${ }_{33}$ B. Bakuła, Kolonialne i postkolonialne aspekty..., op. cit., s. 31.
} 
miona dyskursu kolonialnego, co nawet jeśli nie prowadzi wprost do wskrzeszenia sentymentów imperialnych, to jednak stanowi współczesne powielenie dawnych stosunków zależnościowych.

Świadomość tego niebezpieczeństwa miał np. Tadeusz Chrzanowski, gdy wprawdzie nie tak dawno, niemniej jednak jeszcze przed inauguracją badań postkolonialnych $\mathrm{w}$ Polsce - pisał $\mathrm{w}$ nieco patetycznym stylu, uprzedzając niejako obecne debaty metodologiczne i dyskusje polityczne:

Bracia Ukraińcy, Białorusini, Litwini, Łotysze, bracia Rumuni, Węgrzy i Czesi, bracia
Niemcy i ktokolwiek jeszcze do tej dziwacznej koine należy: historia, która się tędy
przetaczała i przetacza nieustannie, jest naszą wspólną historią. Zabytki, które prze-
trwały na tych obszarach, tak okrutnie niszczonych i gwałconych, są nasze. Nasze
wspólne. Nie roszczę pretensji do ziem, które niegdyś wchodziły w skład naszego pań-
stwa, tak jak nie życzę sobie, by ktokolwiek rościł pretensje do ziem wchodzących dziś
w obręb Trzeciej Rzeczypospolitej. Ale nigdy nie zrezygnuję z pamięci o tych faktach,
które są elementami składowymi mej ojczystej historii, tak jak i wam nie odmawiam
prawa do tego, co przetrwało między Bugiem i Sanem a Wisłą, jako do składnika wa-
szych dziejów ${ }^{34}$.

W podobnym duchu Stanisław Uliasz sformułował postulat konfrontowania polskiego punktu widzenia ,z pozostałymi uczestnikami komunikacji społecznej, reprezentowanymi przez twórców innych kultur i narodów, którzy współzamieszkiwali dawne obszary pogranicza wschodniego Rzeczypospolitej"35. Zauważmy, że zarówno deklarowana wyżej postawa historyka sztuki, jak i zgłoszona przez rzeszowskiego literaturoznawcę propozycja palimpsestowej lektury „Kresów” z ich twórczością i dyskursami, wydają się odległe od "tekstualnego zawłaszczenia” i „dyskursywnej dominacji”, przed którymi przestrzegają teoretycy postkolonialni. Problem zatem tkwi gdzie indziej: $w$ tym, że stanowiska te mogą nie przełożyć się na praktykę badawczą bądź pozostać jedynie z sferze ogólnych deklaracji i wishful thinking, nie znajdując zastosowania w postaci szczegółowych dyrektyw metodologicznych. Że tak faktycznie jest, jasno wynika z katalogu cech prac kresoznawczych, opublikowanych po 1989 r., sporządzonego przez B. Bakułę ${ }^{36}$. Uliasz przyznaje, że "geografia i aksjologia wspólnot kresowych są niesłychanie zróżnicowane. Niejednokrotnie w ten sposób dawały o sobie znać obawy przed zniewalającą atrakcyjnością polskiego wzorca kulturowego" 37 . Stąd, $\mathrm{w}$ imię prawdy o ludzkim doświadczeniu, o doświadczeniu historycznym całych zbiorowości, trzeba serio potraktować imperatyw wpisany w etos współczesnego humanisty: potrzebę wrażliwości na delikatną materię tegoż doświadczenia, reali-

\footnotetext{
34 T. Chrzanowski, op. cit., s. 16, 18.

${ }^{35}$ St. Uliasz, op. cit., s. 35.

36 B. Bakuła, Kolonialne i postkolonialne aspekty..., op. cit., s. 25.

37 St. Uliasz, op. cit., s. 37.
} 
zującą się postawą szacunku wobec cudzych losów i świadomością różnicy kulturowej, prowadzącą do akceptacji ich różnorodnych interpretacji. Jedną z korzyści stanowiska postkolonialnego jest właśnie to, iż odsłania ono z całą ostrością pułapki monocentryczności i monoperspektywiczności takich dyskursów, jak dyskurs kresoznawczy, zmuszając do namysłu nad sposobami ich uniknięcia. Warto w tym kontekście przywołać przestrogę, jaką zawarł E. Said na ostatnich stronicach Orientalizmu:

Współczesna myśl i doświadczenie nauczyły nas czujności wobec tego, co zawsze uwikłane jest w przedstawianie i badanie „innego", w myślenie rasowe, w bezmyślną i bezkrytyczną akceptację autorytetów i modnych idei, w społeczno-polityczną rolę intelektualistów; nauczyły nas cenić świadomość sceptyczną i krytyczną. Być może, jeśli będziemy pamiętali, że studia nad sprawami ludzkimi zawsze mają jakieś następstwa etyczne, nie mówiąc już o politycznych, zarówno dobre, jak złe - będziemy uważniej kontrolować to, co robimy jako naukowcy. Ale czy może być dla uczonego ważniejsza norma niż ludzka wolność i wiedza? Być może, będziemy więc także pamiętać, że badanie człowieka w społeczeństwie oparte jest na konkretnej ludzkiej historii i doświadczeniu, a nie na profesorskich abstrakcjach czy na niejasnych prawach i wymyślonych systemach ${ }^{38}$.

W taki oto sposób Orientalizm, zrealizowawszy swój centralny zamysł krytyczny, szkicuje ogólne ramy postulowanych badań humanistycznych. Czym te ramy wypełnić w odniesieniu do dyskursu kresoznawczego? Jedną z możliwości przedstawił Bakuła w swoim projekcie „komparatystyki integralnej”39. Pomysł ten zasługuje na uwagę jako droga przezwyciężenia etnocentrycznych ograniczeń dyskursu kresoznawczego, w której skłonny byłbym widzieć - przy świadomości wszystkich różnic - autonomiczną, autorską realizację postulatu badań nad wielokulturowością dawnej Rzeczypospolitej, zgłoszonego w latach 1990. przez Władysława Panasa ${ }^{40}$. Jednak niezależnie od tego, czy dyskurs ten podąży szlakiem naszkicowanym przez Panasa, czy torem wytyczonym przez Bakułę, wydaje się, że będzie musiał zmierzyć się z podjętym tu problemem postkolonialnej melancholii. W przeciwnym razie trudne, jeśli nie niemożliwe, może się okazać „wspólne odczytywanie Kresów, bez wzajemnych wykluczeń, potraktowane jako rozpoznawanie wspólnego dziedzictwa na zasadzie nieupodrzędnianych porównań, z obowiązkiem uwzględniania innych racji" 41 .

38 E. W. Said, Orientalizm. Przeł. W. Kalinowski. Warszawa 1991, s. 467.

39 B. Bakuła, Kilka uwag na temat komparatystyki integralnej, w: Historia i komparatystyka. Szkice o literaturze i kulturze Europy Środkowo-Wschodniej XX wieku. Poznań 2000.

${ }^{40}$ Mimo iż sam autor tej projektu „komparatystyki integralnej” zapewne odżegnywałby się od takiej interpretacji swojej propozycji. Zob. W. Panas, O pograniczu etnicznym $w$ badaniach literackich, w: Wiedza o literaturze i edukacja. Księga referatów Zjazdu Polonistów. Red. T. Michałowska, Z. Goliński, Z. Jarosiński. Warszawa 1995. Por. B. Bakuła, Kolonialne i postkolonialne aspekty..., op. cit., s. 21 n.

${ }^{41}$ B. Bakuła, Kolonialne i postkolonialne aspekty..., op. cit., s. 32. 
Czy bowiem dyskurs kresoznawczy skazany jest na zawieszenie między dwiema skrajnościami: $\mathrm{z}$ jednej strony studiami postkolonialnymi $\mathrm{w}$ wersji, która nie rozpoznaje postkolonialnej melancholii, jaką się ów dyskurs żywi, a z drugiej - tradycyjnie pojmowanymi badaniami historycznoliterackimi, dla których melancholia ta stanowi ukrytą i nieuświadamianą siłę napędową? Wyjściem z tego stanu zawieszenia może być włączenie owej melancholii w pole przedmiotowe badań postkolonialnych nad „Kresami” i twórczością „kresową" oraz obejmującymi je dyskursami krytycznymi. Nie chodzi tu ani o poszukiwanie usprawiedliwień dla tego środka "kulturowej samoobrony”, ani o jego potępienie, lecz o postawę rozumiejącą w stosunku do mechanizmów jego funkcjonowania, w które my również jesteśmy zaangażowani, z racji przynależności do tej czy innej wspólnoty interpretacyjnej. Więcej pożytku przyniesie uświadomienie sobie, że mamy do czynienia z chorobą, która nęka organizm populacji i która do pewnego stopnia oddziałuje również na humanistykę. Opisana tu melancholia to symptom tego schorzenia - spektakularny, a także kłopotliwy, lecz jeden z wielu, obok takich objawów, jak kryzys tożsamości, kompleks niższości czy zachowania kompensacyjne. Chorobę tę, której etiologia ma wyraźne podłoże kolonialne, teoretycy nazwali "syndromem postkolonialnym”, dostrzegając w niej zjawisko "typowe dla krajów, które odzyskały niepodległość". Charakteryzuje ją ",szeroka amplituda emocji”, od „euforii wywołanej wiarą, że niepodległość automatycznie rozwiąże wszystkie nagromadzone problemy poprzedniego reżimu”, po „utratę iluzji, frustrację, a nawet depresję"42. Gdzieś w tej rozległej amplitudzie lokowałaby się również melancholia dyskursu kresoznawczego, która tak jak i pozostałe „emocje” - żywi się pamięcią obcej dominacji i nosi na sobie jej piętno. Owej szczególnej choroby "polskiej duszy”, o której mowa - postkolonialnej melancholii - nie sposób zatem sprowadzić do fiksacji na obiekcie utraconym przez dawne imperium. Stąd sugestia, by należące niegdyś do państwa polskiego „Kresy” traktować jako odpowiednik Saidowskiego „Orientu”, czyli przestrzeń poddaną mechanizmom przemocy tekstualnej, niezupełnie utrafia w sedno problemu. Zważywszy na przedstawioną tu argumentację, paralelę tę należałoby sproblematyzować, rozbudowując ją o jeszcze jeden człon. Jeśli trzymać się języka psychoanalizy, powstałą w ten sposób, nową paralelę można by określić następująco: „Kresy” jako esencja narcystycznej cząstki polskiego podmiotu i idealizowany obiekt melancholii Polaków, pielęgnowany w pamięci kulturowej w warunkach długotrwałego skolonizowania. Odpowiedź na pytanie, czy mamy do czynienia z patologią, jak chcą niektórzy, czy z "polityką pamięci”, realizowaną intuicyjnie i spontanicznie w ramach procesów narodotwórczych opisanych przez Anthony'ego Smitha43, pozosta-

\footnotetext{
42 S. Ankrava, The Postcolonial Syndrome and Identity Crisis in Latvia. "Scientific Papers University of Latvia" 2004, t. 666: Literature, Folklore, Arts, s. 26.

${ }^{43}$ Zob. A. D. Smith, Etniczne źródła narodów. Przeł. M. Głowacka-Grajper. Kraków 2009, zwłaszcza rozdz. Legendy i krajobrazy, s. 265 n.
} 
wiam czytelnikom. Uważam natomiast, że wszelka próba dowodzenia kolonialnego charakteru polskiego dyskursu kresoznawczego bez zwrócenia odpowiedniej uwagi na jego szerszy kontekst, tj. rosyjski i sowiecki kolonializm, będzie ocierała się o nadużycie teorii postkolonialnej, a także prowadziła do deformacji, i w konsekwencji niezrozumienia, procesów historycznych ${ }^{44}$. Nie sposób bowiem rozpatrywać kolonialnego wymiaru polskiej obecności na „Kresach” z pominięciem wpływu, jaki na polską tożsamość wywarło spotkanie z Rosją i ZSRR ${ }^{45}$. (Badania nad analogicznym wpływem tego spotkania na tożsamość ukraińską stanowią przedmiot ukraińskich studiów postkolonialnych ${ }^{46}$ ). To w wyniku tego spotkania wielonarodowa Rzeczpospolita utraciła "Kresy” i to w jego konsekwencji polska podmiotowość uległa destabilizacji, została pozbawiona siły sprawczej i stała się podatna na melancholię, o której mowa. Tak więc zarówno termin „Kresy”, jak i dyskursy inspirowane jego desygnatem wskazują - wypada powtórzyć - na istotny brak, deficyt, wyrwę $\mathrm{w}$ tożsamości sprawiającą, iż podmiot melancholii doznaje rozszczepienia czy też „pęknięcia” 47 . „Fizyczne i duchowe przenosiny z wielokulturowej wspólnoty do jednorodnego państwa o zawężonym obszarze żywej tradycji"48 stanowiłyby zatem, w proponowanym tu ujęciu, "punkt zerowy", moment inicjalny procesu, którego skala, zasięg i doniosłość kulturowa wykraczają poza wąskie historyczne uwarunkowania i ich najbardziej bezpośrednie skutki. Dotyczą wspólnoty narodowej jako całości, która w swoim repozytorium przechowuje, za pośrednictwem dyskursów kulturalnych, pamięć o własnych doświadczeniach, modelując zarazem obraz „Innych" - a czyni to wedle rozmaitych wzorów, których opis i typologizacja za pomocą kategorii teorii postkolonialnej to zadanie dla badaczy twórczości „kresowej" oraz dyskursów jej poświęconych.

${ }_{44}$ Przykładu takiej perspektywy, odciętej od szerszego kontekstu, dostarcza szkic F. Wasyla, Kresy wschodnie jako kolonialna metafora historiografii polskiej, op. cit.

45 Moja propozycja stanowiłaby swego rodzaju „lustrzane odbicie” koncepcji Juliusza Mieroszewskiego (Rosyjski kompleks Polski i obszar ULB, „Kultura” 1974, nr 9 (324). Przedr. w: Nie jesteśmy ukrainofilami. Polska myśl polityczna wobec Ukraińców i Ukrainy. Antologia tekstów. Red. P. Kowal, J. Ołdakowski, M. Duchniak. Wrocław 2002, s. 316), który podkreślał niemożność dyskutowania „stosunków polsko-rosyjskich w oderwaniu od obszarów ULB [Ukrainy - Litwy - Białorusi - D.S.], ponieważ stosunki polsko-rosyjskie były zawsze funkcją sytuacji, jaka w danym okresie historycznym panowała na tych obszarach". W proponowanym tu ujęciu warunkiem sensownego uprawiania refleksji nad polskim dyskursem o terytoriach dawnych „Kresów” Rzeczypospolitej jest uwzględnienie rosyjskiego i sowieckiego tła tych relacji.

46 Zob. np. M. Shkandrij, Russia and Ukraine: Literature and Discourse of Empire from Napoelonic to Postcolonial Times. Montreal 2001.

${ }^{47}$ Zob. P. Dybel, Melancholia - gra pozorów i masek. Koncepcja melancholii Sigmunda Freuda, w: Urwane ścieżki. Przybyszewski - Freud - Lacan. Kraków 2000, s. 150.

48 J. Jarzębski, Exodus (ewolucja obrazu kresów po wojnie), w: W Polsce czyli wszędzie. Warszawa 1992, s. 129. 